\title{
P53 mutation compared with Ki67 marker in metastasis of breast cancer in western I ran
}

\author{
Mehrdad Payandeh ${ }^{1}$, Masoud Sadeghi ${ }^{2}$, Adel Fekri' ${ }^{2}$, Edris Sadeghi ${ }^{2}$ \\ 1. Department of Haematology and Oncology, Medical Biology Research Centre, Kermanshah University of Medical \\ Sciences, Kermanshah, Iran. 2. Medical Biology Research Centre, Kermanshah University of Medical Sciences, \\ Kermanshah, Iran.
}

Correspondence: Masoud Sadeghi. Address: Medical Biology Research Centre, Kermanshah University of Medical Sciences, Kermanshah, Iran. Email: sadeghi_mbrc@yahoo.com

Received: May 10, 2014

DOI : $10.5430 /$ jst.v4n3p4
Accepted: July 17, 2014

URL: http://dx.doi.org/10.5430/jst.v4n3p4

\section{Abstract}

Objective: To investigate and compare the prognostic value of P53 and Ki67 markers with age and metastasis and survival in patients with breast cancer in Kermanshah, western Iran.

Methods: In our study on 116 patients with breast cancer that all of them were women and kind of pathology was invasive ductal carcinoma and patients had Her2 positive. The expression of ki67 marker and p53 genes were determined by immunohistochemistry. Statistical analysis was performed with SPSS version IBM 19 and Disease free survival was calculated using the Kaplan-Meier method and log-rank test. Patients were followed up to 5 years.

Results: The age mean of patients was $46.5 \pm 10.75$.Of 116 patients, 23 patients $(19.8 \%)$ had breast cancer with metastasis and $93(80.2 \%)$ without metastasis. expression of P53 (50\%) in 58 patients was positive and 58(50\%) was negative. there is a statistically significant relationship between the p53 and metastasis $(P<0.05)$, but no for Ki67. The over expression of p53 protein and Ki67 had no significant relationship with survival rate $(P>0.05)$.

Conclusions: The results showed that the Ki67 marker and P53 protein are important factors in the breast cancer patients with emphasis on therapeutic agents.

\section{Key words}

Breast cancer, P53, Ki67, Metastasis

\section{Introduction}

Breast cancer screening and higher quality mammography have resulted in an increase in the diagnosis of ductal carcinoma in situ worldwide ${ }^{[1]}$, it is characterized by a number of genetic aberrations. Although improvements have been achieved in recent years, few genetic biomarkers are available to easily identify individuals at risk for breast cancer or breast cancer progression ${ }^{[2]}$. A lot of studies ${ }^{[3-6]}$ investigated p53 protein and Ki67 marker in breast cancer patients and analyze correlation between these markers. And other studies ${ }^{[3,6,7]}$ reviewed association between p53 protein and Ki67 marker with survival rate. 
Though some studies ${ }^{[5,7]}$ showed that p53 and Ki67 were valuable markers for prognosis of breast cancer and survival rate. But other studies ${ }^{[3,8]}$ and our study showed that there aren't relationship between these biomarkers with survival rate and prognosis of breast cancer.

Results of the study suggested that the p53 protein and Ki67 marker aren't important factors in the prognosis of metastasis and survival rate in patients with breast cancer in western Iran.

\section{Methods}

\subsection{Patients and materials}

We studied 116 women patients with breast cancer who their kind of pathology was invasive ductal carcinoma. HER2 protein expression of patients was detected by IHC, and Patients were categorized on the basis of IHC values as +2 and +3 .

Samples were collected before the patients received any radiotherapy and/or chemotherapy. The specimens for pathology reports were fixed in $10 \%$ neutral-buffered formalin $(\mathrm{pH}=7.4)$ for 24 hours, then sliced into $4-\mu \mathrm{m}$ sections. Her- 2 protein expression was measured using a commercial available S-P kit. FISH for Her-2 gene amplification was performed in laboratory of Imam Reza Hospital using a commercial available double-color probe. Monoclonal antibodies against Ki67, p53 and HER2, as well as IHC kit were purchased from Pars Azmon Co. Equivalent phosphate-buffered saline (PBS) was used as a negative control for primary antibodies.

\subsection{Statistical analysis}

Statistical analysis was performed with IBM SPSS software version 19, and the enumeration data were compared with the Fisher's exact test and chi-square test. $P \leq 0.05$ was considered to indicate a statistically significant difference (95\% CI). Disease free survival (DFS) was calculated using the Kaplan-Meier method and log-rank test. DFS is defined as the time from randomization until death or metastasis of tumor (for 5 years).

\section{Result}

A total of 116 cases with breast cancer were involved that all of them were women. The age mean of patients was 46.5 \pm 10.75 (range, 24-78). 34 patients(29.3\%) had IHC 2+ and 82(70.7\%) had IHC 3+. All of patients were treated with radiotherapy, chemotherapy, hormone therapy and $38.7 \%$ of patients were treated with Trastuzumab. The 23 patients $(19.8 \%)$ had breast cancer with metastasis and $93(80.2 \%)$ without metastasis. We divided patients to two groups, $\geq 40$ years and $<40$ years. Of 116 patients, 83 patients $(71.5 \%)$ were $\geq 40$ years and 33 patients $(28.4 \%)$ were $<40$ years.

Table 1. Correlation of between P53 and Ki67 with age

\begin{tabular}{|c|c|c|c|}
\hline \multirow{2}{*}{ Expression of marker } & \multicolumn{2}{|c|}{ Age, year n(\%) } & \multirow{2}{*}{$P$-value } \\
\hline & $\geq 40$ & $<40$ & \\
\hline \multicolumn{4}{|l|}{ p53, n(\%) } \\
\hline+ & $44(75.8)$ & $14(24.2)$ & \multirow{2}{*}{$P>0.05^{*}$} \\
\hline- & $39(67.2)$ & $19(32.8)$ & \\
\hline \multicolumn{4}{|l|}{ Ki67, n(\%) } \\
\hline$<10 \%$ & $21(65.6)$ & $11(34.4)$ & \multirow{3}{*}{$P>0.05^{\#}$} \\
\hline$>10 \%$ & $52(72.2)$ & $20(27.8)$ & \\
\hline- & $10(83.3)$ & $2(16.4)$ & \\
\hline
\end{tabular}

"Fisher's exact test; ${ }^{*}$ chi-square test 


\section{Expression of p53 protein and Ki67 marker}

Table 1 shows a correlation of between p53 and Ki67 with age. The results showed that there isn't a statistically significant between p53 with age, and Ki67 with age, too.

In this study, expression of P53 (50\%) in 58 patients was positive and 58(50\%) was negative. Ki67 marker expression in 32 patients $(27.6 \%)$ was $<10 \%$ in tumors, $72(62.1 \%)$ was $>10 \%$ and $12(10.3 \%)$ was negative.

Table 2 shows that there is a statistically significant relationship between the p53 and metastasis in patients, but there isn't a significant relationship between Ki67 and metastasis.

Table 2. Relationship of between p53 and Ki67 with metastasis in patients simultaneously with adjuvant therapy

\begin{tabular}{|c|c|c|c|}
\hline \multirow{2}{*}{ Expression of marker } & \multicolumn{2}{|c|}{ Metastasis n(\%) } & \multirow{2}{*}{$P$-value } \\
\hline & + & - & \\
\hline \multicolumn{4}{|l|}{ p53 } \\
\hline+ & $7(30.4 \%)$ & $51(54.8 \%)$ & $P<0.05^{*}$ \\
\hline - & $16(69.6 \%)$ & $42(45.2 \%)$ & \\
\hline Ki67 & & & $P>0.05^{\#}$ \\
\hline$<10 \%$ & $3(13 \%)$ & $29(31.2 \%)$ & \\
\hline$>10 \%$ & $16(69.6 \%)$ & $56(60.2 \%)$ & \\
\hline- & $4(17.4 \%)$ & $8(8.6 \%)$ & \\
\hline
\end{tabular}

"Fisher's exact test; " chi-square test

DFS for 5 years after to expression of p53 and Ki67 by IHC have been showed in Figure 1 and Figure 2. A few of women were lost to follow-up before completing a one-year period and should therefore be excluded from the analysis. The results showed that the over expression of p53 protein had no significant relationship with survival rate $(P>0.05,95 \% \mathrm{CI}$ of ratio $=0.59$ to 3.19 , Hazard ratio=1.37). Mean of DFS for patients with p53 positive was 32 months and for patients with p53 negative was 38 months. The five-year survival rate for p53 positive and negative were $77.7 \%$ and $77.2 \%$, and the five-year survival rate for Ki67<10\% and $>10 \%$ were $83.8 \%$ and $68.8 \%$, respectively.

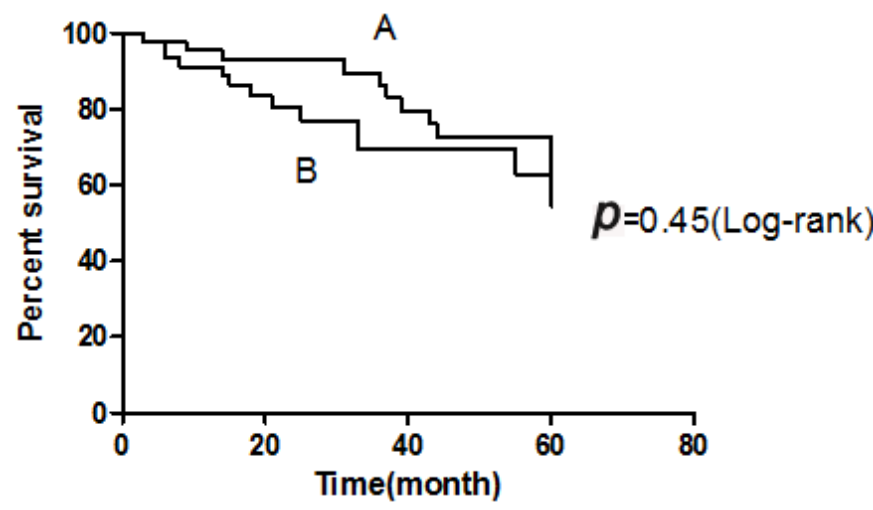

Figure 1. Disease free survival for expression of P53 in patients with Her2 positive simultaneously with adjuvant therapy (A) in patients with P53 positive (B) in patients with P53 negative

Figure 2 shows that percentage of Ki67 protein in tumors had no significant relationship with survival rate $(P>0.05,95 \%$ $\mathrm{CI}$ of ratio $=0.2$ to 1.3 , Hazard ratio $=0.52$ ). Mean of DFS for patients with Ki67 $<10 \%$ in tumors was 33 months and for patients with Ki67 $>10 \%$ in tumors was 30 months. 


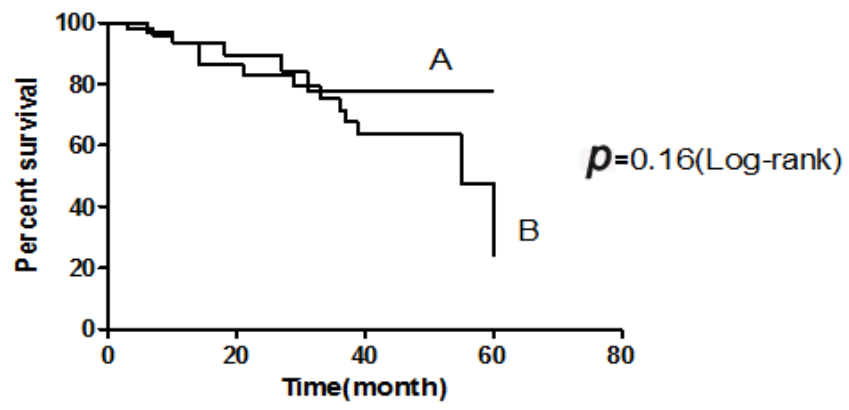

Figure 2. Disease free survival for expression of Ki67 in patients with Her2 positive simultaneously with adjuvant therapy (A) in patients with Ki67 $<10 \%$ in tumors (B) in patients with Ki67 $>10 \%$ in tumors

\section{Discussion}

Ki67 marker and p53 gene most often used to evaluate tumor proliferation status, including breast cancer ${ }^{[3,6]}$. But value of p53 and Ki67 markers have not been yet established as a constant factor in determination of the prognosis of breast cancer $^{[3]}$.

Our study in western Iran, recently study ${ }^{[9]}$ and also in eastern Iran ${ }^{[10]}$ show that mean of age in women with breast cancer is around 45 to 50 years, but other recently studies ${ }^{[11,12]}$, in northwest Iran ${ }^{[13]}$ and in western $\operatorname{Iran}^{[14]}$ show that mean of age is around 50 to 70 years. In center of Iran the mean was lower ${ }^{[15]}$. Therefore, based on the studies this result is achieved that mean of age in breast cancer is more between 20 to 70 years. Reduce of patients age shows that factors of disease can be associated with living conditions in childhood and youth.

Studies ${ }^{[3,16]}$ showed that expression of $\mathrm{p} 53$ protein was $49 \%$ in patients with breast cancer, and also our results in this study was similar with them. There is a significant relationship between 53 and metastasis of breast cancer (Table 2).But in this study, it was determined that in patients with metastasis (23 cases), 16 cases (69.5\%) had p53 negative, and this result is opposite with other studies ${ }^{[17-20]}$. Adjuvant therapy in our patients has been reduced metastasis in breast cancer, even in patients with $\mathrm{p} 53$ positive.

In this study in patients with metastasis, 16 patients (69.5\%) had Ki67 $>10 \%$ in tumors. Also, in patients with Ki67 positive, more patients didn't have metastasis, and there is no significant relationship between Ki67 with metastasis $(P>0.05)$ such as Gojis $\mathrm{O}$ and et al ${ }^{[21]}$, and Tvedskov TF and et al ${ }^{[22]}$. Some of other studies ${ }^{[23-26]}$ showed that Ki67 had a significant relationship with metastasis.

The p53 mutation in breast cancer patients is associated with statistically significant reduced DFS ${ }^{[27-29]}$, but our results in this study such as results of Golmohammadi $\mathrm{R}$ and et al ${ }^{[3]}$ showed that the over expression of P53 protein have no significant relationship with survival rate.

The presence of the Ki67 marker had significant relationship with survival rate ${ }^{[3,30]}$, but our study shows that there is no significant relationship between Ki67 and survival rate. Hazard ratio for p53 is 1.37, but for Ki67 is 0.52 . Therefore, this shows that factor p53 is more important of ki67 on survival rate. In our study, patients were treated with radiotherapy, chemotherapy, hormone therapy and $38.7 \%$ of patients were treated with Trastuzumab. In our study, mean of DFS for patients with p53 negative and Ki67 $<10 \%$ is better than p53 positive and Ki67>10\%. Differences in studies show that adjuvant therapy can effect on results of p53 and Ki67 with metastasis and survival rate and even can reduce metastasis and increase survival rate in patients with $\mathrm{p} 53$ positive and Ki67 positive. 
These results demonstrate that p53 mutation and Ki67 marker can predict metastasis in women with breast cancer with emphasis on therapeutic agents. Therefore, in other studies must be determined kind and time of treatment and it needs larger studies in future.

Results of the study suggested that the p53 protein and Ki67 marker are important factors in the prognosis of metastasis and survival rate in patients with breast cancer. It must take into consideration other factors in breast cancer and their correlation with each other. Also, it is probably important that patients of IHC 2+ with Ki67 positive or p53 positive get treated with adjuvant therapy.

\section{Acknowledgement}

The authors thank Mr. Gholami for technical assistance.

\section{References}

[1] Omranipour R, Alipour S, Hadji M, Bagheri K. Two decades of experience with ductal carcinoma in situ of the breast in the cancer institute of tehran, iran. Asian Pac J Cancer Prev. 2014; 15(6): 2771-6. PMid:24761899 http://dx.doi.org/10.7314/APJCP.2014.15.6.2771

[2] Yu Q, Li Y, Mu K, Li Z, Meng Q, Wu X, Wang Y, Li L1. Amplification of Mdmx and overexpression of MDM2 contribute to mammary carcinogenesis by substituting for p53 mutations. Diagn Pathol. 2014 Mar 25; 9: 71. PMid:24667108 http://dx.doi.org/10.1186/1746-1596-9-71

[3] Golmohammadi R, Pejhan A. The prognostic value of the P53 protein and the Ki67 marker in breast cancer patients. J Pak Med Assoc. 2012 Sep; 62(9): 871-5. PMid:23139965

[4] Mitrović O, Cokić V, Dikić D, Budeč M, Vignjević S, Subotički T, Gulan M, Radović S, Furtula S. Correlation between ER, PR, HER-2, Bcl-2, p53, proliferative and apoptotic indexes with HER-2 gene amplification and TOP2A gene amplification and deletion in four molecular subtypes of breast cancer. Target Oncol. 2013 Nov 24.

[5] Shapochka DO, Zaletok SP, Gnidyuk MI. Relationship between NF-кB, ER, PR, Her2/neu, Ki67, p53 expression in human breast cancer. Exp Oncol. 2012 Dec; 34(4): 358-63. PMid:23302996

[6] Kobayashi T, Iwaya K, Moriya T, Yamasaki T, Tsuda H, Yamamoto J, Matsubara O. A simple immunohistochemical panel comprising 2 conventional markers, Ki67 and p53, is a powerful tool for predicting patient outcome in luminal-type breast cancer. BMC Clin Pathol. 2013 Feb 6; 13: 5. PMid:23384409 http://dx.doi.org/10.1186/1472-6890-13-5

[7] Engels CC, Ruberta F, de Kruijf EM, van Pelt GW, Smit VT, Liefers GJ, Matsushima T, Shibayama M, Ishihara H, van de Velde CJ, Kuppen PJ. The prognostic value of apoptotic and proliferative markers in breast cancer. Breast Cancer Res Treat. 2013 Nov; 142(2): 323-39. PMid:24194179 http://dx.doi.org/10.1007/s10549-013-2748-y

[8] Klintman M, Bendahl PO, Grabau D, Lövgren K, Malmström P, Fernö M.The prognostic value of Ki67 is dependent on estrogen receptor status and histological grade in premenopausal patients with node-negative breast cancer. South Sweden Breast Cancer Group Mod Pathol. 2010; 23: 251-9.

[9] Hamadeh RR, Abulfatih NM, Fekri MA, Al-Mehza HE. Epidemiology of Breast Cancer among Bahraini Women: Data from the Bahrain Cancer Registry. Sultan Qaboos Univ Med J. 2014 May; 14(2): e176-82. PMid:24790739

[10] Najmabadi KM, Azarkish F, Latifnejadroudsari R, Shandiz FH, Aledavood SA, Kermani AT, Esmaily HO.Self-disclosure of breast cancer diagnosis by Iranian women to friends and colleagues. Asian Pac J Cancer Prev. 2014; 15(6): $2879-82$. PMid:24761918 http://dx.doi.org/10.7314/APJCP.2014.15.6.2879

[11] Ortiz-Mendoza CM, de-la-Fuente-Vera TA, Pérez-Chávez E. Metabolic syndrome in Mexican women survivors of breast cancer: a pilot study at a general hospital. Med Arh. 2014; 68(1): 19-21. http://dx.doi.org/10.5455/medarh.2014.68.19-21

[12] Pasko J, Schray M, Lee M, Johnson N. Experience with partial breast irradiation for treatment of breast cancer at a community-based cancer center. Am J Surg. 2014 May; 207(5): 682-5. PMid:24791627 http://dx.doi.org/10.1016/j.amjsurg.2013.12.025

[13] Sanaat Z, Halimi M, Ghojezadeh M, Pirovi AH, Gharamaleki JV, Ziae AE, Kermani IA. Immunohistochemical Analysis of p53, Ki-67, CD44, HER-2/neu Expression Patterns in Gastric Cancer, and Their Association with One Year Survival in North-West of Iran. Int J Hematol Oncol Stem Cell Res. 2013; 7(3): 15-20. PMid:24505530 
[14] Mardanpour K1, Rahbar M. Steroid hormone receptors, MIB-1, p53, and c-erb-B2 expression on breast cancer: Comparison of immunohistochemistry on cell block and fine needle aspiration and tissue sample, in northwest Iran. Caspian J Intern Med. 2012 Fall; 3(4): 523-9. PMid:24009928

[15] Nojomi M, Namiranian N, Myers RE, Razavi-Ratki SK, Alborzi F. Factors Associated with Breast Cancer Screening Decision Stage among Women in Tehran, Iran. Int J Prev Med. 2014 Feb; 5(2): 196-202. PMid:24627747

[16] Tan PH, Chuah KL, Chiang G, Wong CY, Dong F, Bay BH. Correlation of p53 and cerbB2 expression and hormonal receptor status with clinicopathologic parameters in ductal carcinoma in situ of the breast. Oncol Rep. 2002; 9: 1081-6. PMid:12168077

[17] Arjonen A, Kaukonen R, Mattila E, Rouhi P, Högnäs G, Sihto H, Miller BW, Morton JP, Bucher E, Taimen P, Virtakoivu R, Cao Y, Sansom OJ, Joensuu H, Ivaska J. Mutant p53-associated myosin-X upregulation promotes breast cancer invasion and metastasis. J Clin Invest. 2014 Mar 3; 124(3): 1069-82. PMid:24487586 http://dx.doi.org/10.1172/JCI67280

[18] Muller PA, Vousden KH, Norman JC. p53 and its mutants in tumor cell migration and invasion. J Cell Biol. 2011 ; $192(2)$ : $209-218$. PMid:21263025 http://dx.doi.org/10.1083/jcb.201009059

[19] Girardini JE, et al. A Pin1/mutant p53 axis promotes aggressiveness in breast cancer. Cancer Cell. 2011; 20(1): 79-91. PMid:21741598 http://dx.doi.org/10.1016/j.ccr.2011.06.004

[20] Mojarad S, Venturini B, Fulgenzi P, Papaleo R, Brisigotti M, Monti F, Canuti D, Ravaioli A, Woo L, Dlay S, Sherbet GV. Prediction of nodal metastasis and prognosis of breast cancer by ANN-based assessment of tumour size and p53, Ki-67 and steroid receptor expression. Anticancer Res. 2013 Sep; 33(9): 3925-33. PMid:24023330

[21] Gojis O, Kubecova M, Rosina J, Vranova J, Celko M, Frajerova D, Zmrhal J, Zahumensky J, Bacova T, Baca V, Mandys V, Kucera E. Expression of selected proteins in breast cancer brain metastases. Folia Histochem Cytobiol. 2013; 51(3): 213-8. PMid:24203627 http://dx.doi.org/10.5603/FHC.2013.0030

[22] Tvedskov TF, Bartels A, Jensen MB, Paaschburg B, Kroman N, Balslev E, Brünner N. Evaluating TIMP-1, Ki67, and HER2 as markers for non-sentinel node metastases in breast cancer patients with micrometastases to the sentinel node. APMIS. 2011 Dec; 119(12): 844-52. PMid:22085360 http://dx.doi.org/10.1111/j.1600-0463.2011.02768.x

[23] Paksoy SE, Tasdelen I, Balaban AS, Ozkaya G, Tolunay S. A comparison of Ki 67 proliferative index in primary tumor and axillary metastatic lymph nodes with length of survival in patients with breast cancer. Bratisl Lek Listy. 2013; 114(11): 645-9.

[24] Jalava P, Kuopio T, Juntti-Patinen L, Kotkansalo T, Kronqvist P, Collan Y . Ki67 immunohistochemistry: a valuable marker in prognostication but with a risk of misclassification: proliferation subgroups formed based on Ki67 immunoreactivity and standardized mitotic index. Histopathology. 2006; 48: 674-682. PMid:16681683 http://dx.doi.org/10.1111/j.1365-2559.2006.02402.x

[25] Trihia H, Murray S, Price K, Gelber RD, Golouh R, Goldhirsch A, Coates AS, Collins J, Castiglione-Gertsch M, Gusterson BA . Ki-67 expression in breast carcinoma: its association with grading systems, clinical parameters, and other prognostic factors - a surrogate marker? Cancer. 2003; 97: 1321-1331. PMid:12599241 http://dx.doi.org/10.1002/cncr.11188

[26] Tazhibi M, Fayaz M, Mokarian F. Detection of prognostic factors in metastatic breast cancer. J Res Med Sci. 2013 Apr;18(4): 283-90. PMid:24124424

[27] Bonafé M, Ceccarelli C, Farabegoli F, Santini D, Taffurelli M, Barbi C, Marzi E, Trapassi C, Storci G, Olivieri F, Franceschi C. Retention of the p53 codon 72 arginine allele is associated with a reduction of disease-free and overall survival in arginine/proline heterozygous breast cancer patients. Clin Cancer Res. 2003 Oct 15; 9(13): 4860-4. PMid:14581358

[28] Wiltschke C, Kindas-Muegge I, Steininger A, Reiner A, Reiner G, Preis PN. Coexpression of HER-2/neu and p53 is associated with a shorter disease-free survival in node-positive breast cancer patients. J Cancer Res Clin Oncol. 1994; 120(12): 737-42. PMid:7798300 http://dx.doi.org/10.1007/BF01194273

[29] Kobayashi T, Masutomi K, Tamura K, Moriya T, Yamasaki T, Fujiwara Y, Takahashi S, Yamamoto J, Tsuda H. Nucleostemin expression in invasive breast cancer. BMC Cancer. 2014 Mar 21; 14: 215. PMid:24650343 http://dx.doi.org/10.1186/1471-2407-14-215

[30] Ishihara M, Mukai H, Nagai S, Onozawa M, Nihei K, Shimada T, Wada N. Retrospective analysis of risk factors for central nervous system metastases in operable breast cancer: effects of biologic subtype and Ki67 overexpression on survival. Oncology. 2013; 84(3): 135-40. PMid:23235554 http://dx.doi.org/10.1159/000345321 